\title{
Predisposition of 7-10-year-old children to accommodative spasm - findings from studies on the quality of binocular vision
}

\section{Predyspozycja dzieci 7-10-letnich do wystąpienia skurczu akomodacji na podstawie badań jakości widzenia obuocznego}

\author{
Lidia Puchalska-Niedbał ${ }^{\circledR}$, Urszula Kulik², Damian Czepita ${ }^{3}$ \\ 1 Pomorski Uniwersytet Medyczny w Szczecinie, II Katedra i Klinika Okulistyki, al. Powstańców Wlkp. 72, 70-111 Szczecin \\ ${ }^{2}$ St Eriks Ogonsjukhus, Palhemsgatan 50, 11230 Sztokholm, Szwecja \\ ${ }^{3}$ Pomorski Uniwersytet Medyczny w Szczecinie, Studium Praktycznej Nauki Języków Obcych, ul. Ku Słońcu 12, 71-075 Szczecin \\ 凹 lidianiedbal@tlen.pl
}

\begin{abstract}
Introduction: The aim of our study was to evaluate the quality of binocular vision among school children and to indentify symptoms associated with accommodation.

Materials and methods: This study involved 300 children, aged 7-10 years. Two parts were planned: a) a questionnaire - an interview regarding problems associated with accommodative spasm; b) ophthalmic - visual acuity, anterior segment and fundus examination, auto-refractometry, motility and alignment of the eyes, dissociated horizontal phoria to near and distance using the Maddox test. The obtained results were analyzed statistically using Statistica 10 software. P values of $<0.05$ were considered statistically significant.

Results: The following refractive errors were selected: emmetropia ( 52 children), hyperopia ( 9 children), myopia ( 239 children). Degree of spasm achieved: 10 children (3.5-8 SD). The majority
\end{abstract}

of patients showed exophoria (near - 240 children; far - 112 children). The exophoria readings were 5-12 PD. Among children with good visual acuity equal to 1.0 (218 children) exophoria was noted in 180 children; $p=0.29307$. A lack of convergence was most often observed among children with near exophoria ( 158 children); $\mathrm{p}=0.14929$.

Conclusions: Complaints in the form of headaches or ocular pain were provided by children among whom dissociated horizontal phoria were different from the assumed norms. Difficulties concentrating while reading or symptoms of asthenopic character were reported most frequently by children with abnormal values of dissociated phoria, which may predispose them to accommodative spasm.

Keywords: accommodative spasm; heterophoria; myopia; children.

\begin{abstract}
ABSTRAKT
Wstęp: Celem pracy była ocena jakości widzenia obuocznego oparta na pomiarach wybranych parametrów charakteryzujących funkcję układu wzrokowego wśród dzieci szkolnych oraz identyfikacja objawów związanych z akomodacją.

Materiały i metody: Przeprowadzono badania okulistyczne u 300 dzieci (180 dziewczynek, 120 chłopców) w wieku 7-10 lat. Zaplanowane zostały dwie części: a) ankietowa - wywiad na temat dolegliwości towarzyszących skurczowi akomodacji i heteroforii; b) okulistyczna - ocena przedniego odcinka i dna oczu, pomiar ostrości wzroku do dali, badanie refrakcji przed cykloplegią i po cykloplegii, ruchomości i ustawienia oczu, pomiar zdysocjowanej forii horyzontalnej do bliży i do dali metodą Maddoxa. Otrzymane wyniki poddano analizie statystycznej za pomocą programu Statistica 10. Wartość $\mathrm{p}<0,05$ uznano za statystycznie znamienną.

Wyniki: Stwierdzono następujące wady refrakcji: emmetropia (u 52 dzieci), nadwzroczność (9 dzieci), krótkowzroczność
\end{abstract}

(239 dzieci). Skurcz akomodacji występował u 10 dzieci (3,5-8 Dsph). Heteroforia: u większości dzieci występowała egzoforia (do bliży - u 240 dzieci; do dali - u 112 dzieci). Egzoforia do bliży była w przedziale 5-12 Dpryzm. Wśród dzieci z dobrą ostrością wzroku wynoszącą 1,0 (218 dzieci) egzoforię stwierdzono u 180 ( $p=0,29307)$. Brak odruchu zbieżności najczęściej obserwowano u 158 dzieci z egzoforią do bliży ( $p=0,14929)$. Wnioski: Skargi na bóle głowy i oczu najczęściej zgłaszały dzieci ze zdysocjowaną poziomą forią odbiegającą od przyjętej normy. Trudności ze skupieniem w trakcie czytania z bliska oraz objawy o charakterze pogorszenia widzenia najczęściej zgłaszały dzieci z nieprawidłową wartością zdysocjowanej forii, która prawdopodobnie predysponowała do skurczu akomodacji.

Słowa kluczowe: skurcz akomodacji; heteroforia; krótkowzroczność; dzieci.

\section{INTRODUCTION}

Spasm of accommodation (usually functional in origin) is the sudden development of a considerable degree of myopia which disappears after cycloplegia. Spasm of accommodation is a constant or intermittent involuntary and inappropriate ciliary contraction [1]. The tone of the ciliary muscle is increased and a constant accommodative effort is expended by the parasympathetic nervous system, and as a result pseudomyopia is produced [1]. It may be unilateral or bilateral. Symptoms are blurred vision depending on the patient's refractive status, macropsia, asthenopia during close work, pain (headache) $[2,3]$ poor 
concentration, and convergence anomalies (excess or insufficiency) [2]. Naturally, the condition is restricted to age groups in which accommodation is active. The near response triad consists of a normal synkinesis between accommodation, convergence and miosis [4]. While some patients may have isolated accommodative spasm (without involving convergence and pupils) others may show spasm of convergence without abnormal accommodation [5]. Large exophoria or intermittent exotropia has been described as a cause of accommodative spasm $[1,6,7,8]$. It has been observed that when intermittent exotropia is the aetiology, the accommodative spasm is usually intermittent, present under binocular conditions and absent with cycloplegia $[9,10]$.

The aetiology of accommodative spasm is most often functional or idiopathic, although a number of organic causes have been reported. Treatment of functional spasm: eliminate exciting cause, consider occupation, general health, mental state and correct refractive error and/or ocular motor anomaly.

The main objective of the study was to assess the quality of binocular vision based on measurements of selected parameters characterizing the function of the visual system among school children, and to identify the symptoms associated with accommodation.

\section{MATERIALS AND METHODS}

Opthalmic examinations were performed on a group of 300 children (180 girls, 120 boys) aged 7-10 years.

In the questionnaire part of the study an interview regarding the symptoms which may accompany accommodative spasm and heterophoria, such as ocular pain, headaches, transient diplopia, fatigue and difficulty with concentration while reading was completed. Every examined child underwent a thorough eye examination, including: visual acuity, anterior segment and fundus examination, and auto-refractometry before and after cycloplegia. The measurement of dissociated phoria using the Maddox test was carried out in every child in identical conditions (in a dark room to eliminate peripheral visual stimuli to the fusion). The subject observed a spot of light located in the centre of a scale for a given distance Maddox wing (from 5 metres and $30 \mathrm{~cm}$ ). In front of one eye the Maddox rod was introduced, which caused the spot source of light to be seen in the form of a thin strip - vertical when the axis of the groves in the Maddox rod was horizontal and horizontal when the axis of the Maddox rod was set vertically. Appropriate orientation of the Maddox rod allows for the measurement of the axis of deviation in the horizontal and vertical planes. Dissociated phoria was determined by specifying the degree of how much the strip of light has shifted as seen by the eye with the Maddox rod in relation to the spot of light seen with the other eye [11]. Motility of both eyes was tested in 8 directions, and the convergence of both eyes was examined by observing the smoothness of both eyes converging during binocular observation of an approaching object toward the nose.

This study adhered to the guidelines of the Declaration of Helsinki for research in human subjects, and was approved by the ethics committee of the Pomeranian Medical University in Szczecin, Poland.

Written informed consent was obtained from each volunteer prior to measurements.

\section{RESULTS}

\section{Refractive errors}

Preliminary refractive tests were made without cycloplegics. Where spasm was suspected from the symptoms or from the variability of response, cycloplegics were employed before the diagnosis was definitely made. The children were tested under Tropicmide cycloplegia. These tests showed that spasm was confined to the myopic type of refraction: 9 children were hypermetropic, 52 emmetropic, and 239 myopic. Only 2 children showed astigmatism of more than one diopter.

\section{Degree of spasm achieved}

Here again there was considerable variation. Two children achieved 8 SD of spasm, three 6 SD, three 5 SD, one 4 SD, and two 3.5 SD. There were individual exceptions, but the myopies seemed to suffer spasms of higher degree on average than the hypermetropies and emmetropies in the series.

\section{Heterophoria}

This was usually measured with the Maddox test. As would be expected, the majority of patients showed exophoria (240 children), but esphoria for near was noted in a few cases. The near readings in 20 children of esophoria were 3 PD. The exophoria readings were 5-12 PD. Significant hyperphoria was not noted. Among children with good visual acuity (1.0) exophoria was detected in 180 children; $p=0.29307$ (tab. 1). Ocular motility was normal in all the examined children. The lack of convergence was most often observed in children with near exophoria (158 children) - table 2.

In children with exophoria to far, exophoria to near was most often observed; $\mathrm{p}=0.00027$ (tab. 3 ). In children with visual acuity of 1.0 (218 children) while looking into the distance, horizontal exophoria up to 2 PD (87 children) or small esophoria up to $1 \mathrm{DP}$ (70 children) occurred. Ortophoria was present in 61 children (tab. 4).

\section{Associated headaches}

These were not a prominent feature. Only 5 children complained of frontal headache, but no stress was laid on the severity of the symptom. Ocular pain was mentioned in a few cases.

\section{Associated nausea}

This was inquired into for those complaining of headache but was admitted in only two cases.

\section{Associated mental stress}

This was noted in 10 of the 300 children. The factor of mental distress was sufficiently pronounced in most cases to be an inescapable feature. 
TABLE 1. Heterophoria to near and visual acuity among schoolchildren aged 7-10 years

\begin{tabular}{lcccc}
\multicolumn{7}{c}{ Maddox to near } \\
\hline \multicolumn{1}{c}{ VA } & $\mathbf{X}$ & $\mathbf{E}$ & $\mathbf{0}$ & Total \\
\hline 1,0 & 180 & 11 & 27 & 218 \\
\hline $0.3-0.9$ & 54 & 9 & 13 & 76 \\
\hline $0.1-0.2$ & 4 & 0 & 0 & 4 \\
\hline$<0.1$ & 2 & 0 & 0 & 2 \\
\hline Total & 240 & 20 & 40 & 300 \\
\hline$X^{2}$ Pearson & 7.31 & $\mathrm{df}=6$ & $\mathrm{p}=0.29307$ \\
\hline
\end{tabular}

VA - visual acuity; $X$ - exophoria; E - esophoria; O - ortophoria

TABLE 2. Near heterophoria and convergence reflex in schoolchildren aged 7-10 years

\begin{tabular}{lcccc}
\multicolumn{7}{c}{ Maddox to near } \\
\hline Convergence & $\mathbf{X}$ & $\mathbf{E}$ & $\mathbf{0}$ & Total \\
\hline Lack & 158 & 12 & 20 & 190 \\
\hline Normal & 82 & 8 & 20 & 110 \\
\hline Total & 240 & 20 & 40 & 300 \\
\hline$X^{2}$ Pearson & 3.80 & $\mathrm{df}=2$ & $\mathrm{p}=0.14929$ \\
\hline
\end{tabular}

X-exophoria; E - esophoria; O - ortophoria

TABLE 3. Maddox test to far and Maddox test to near - number of schoolchildren in the ages 7-10 years

\begin{tabular}{lcccc}
\multicolumn{7}{c}{ Maddox to far } \\
Maddox to near & E & $\mathbf{0}$ & $\mathbf{X}$ & Total \\
\hline $\mathrm{X}$ & 83 & 53 & 104 & 240 \\
\hline $\mathrm{E}$ & 12 & 4 & 4 & 20 \\
\hline $\mathrm{O}$ & 17 & 18 & 5 & 40 \\
\hline Total & 112 & 75 & 113 & 300 \\
\hline $\mathrm{X}^{2}$ Pearson & 21.37 & $\mathrm{df}=4$ & $\mathrm{p}=0.00027$ \\
\hline
\end{tabular}

E - esophoria; O - ortophoria; X - exophoria

TABLE 4. Far heterophoria with respect to visual acuity

\begin{tabular}{|c|c|c|c|c|}
\hline \multicolumn{5}{|c|}{ Maddox to far } \\
\hline VA & $\mathbf{E}$ & 0 & $\mathrm{X}$ & Total \\
\hline 1 & 70 & 61 & 87 & 218 \\
\hline $0.3-0.9$ & 42 & 13 & 21 & 76 \\
\hline 01-02 & 0 & 1 & 3 & 4 \\
\hline$<0.1$ & 0 & 0 & 2 & 2 \\
\hline Total & 112 & 75 & 113 & 300 \\
\hline$x^{2}$ Pearson & 19.41 & $d f=6$ & $p=$ & 52 \\
\hline
\end{tabular}

VA - visual acuity; E - esophoria; O - ortophoria; X-exophoria

\section{DISCUSSION}

In an era of great availability of smart phones and computers, the fact that more younger children use these devices frequently without adult supervision is disturbing. We have noted a large number of children who use these devices for at least 2 hours daily. In 10 children we found the accommodative spasm to be 5-8 SD. In 218 out of the 300 examined children visual acuity was normal (1.0). However, refractive examinations showed myopia from -0.50 to $-4.5 \mathrm{SD}$, which completely disappeared after cycloplegia.
Newfoundland Richler and Bear [12], after examining 971 people aged 5 years and above, showed that the level of education and near visual work lead to a higher occurrence of myopia. In 1987 the most widely-ranging research concerning the topic was conducted by Rosner and Belkin [13]. The authors studied 157,748, 17-19-year-old Israeli male recruits. They demonstrated that an increase in the level of education leads to increased prevalence of myopia. In 1988 Teasdale and Goldschmidt carried out extensive research on the impact of educational level on the occurrence of myopia [14]. After examining 7,950 men 18-years-old appearing before the draft board in eastern Denmark, they found that myopia is more common in people with higher education. Nevertheless, the data were not statistically significant. Saw et al. discovered among 429 18-23-year-old military con-scripts from Singapore that myopia is more common in people with higher education, which they explained by the increased near vision workload and the influence of genetic factors [15]. In 2008 Konstantopoulos et al. published studies on the impact of educational level on the occurrence of myopia [16]. Periodic accommodative spasm may act as a signal of preceding myopia. The symptoms may not be noted or understood by children, and the prolonged accommodative spasm condition can lead to overt myopia. The term "spasm of accommodation" is frequently used by ophthalmologists. In some young hypermetropes the ciliary muscle is maintained in a condition of partial contraction, which may compensate partly or fully for the amount of hypermetropia. This is not accommodative spasm and should not be called by that name. It is a physiological adaptation in the interests of clear vision, and in all probability is attained by the action of the circular ciliary muscle alone, which, like other sphincter muscles in the body, easily lends itself to the maintenance of a state of tonic contraction. A small degree of spasm of the ciliary muscle undoubtedly exists in a definite proportion of myopes, especially among uncorrected myopic school children. This seldom amounts to more than 1 SD or 2 SD and is not spasm of accommodation. It may only be a phenomenon associated with the increased convergence that uncorrected myopies and astigmatics adopt to get clearer vision. True spasm of accommodation may be defined as the sudden development in one or both eyes of a high degree of apparent myopia which disappears under the influence of cycloplegia. The spasm may be either continuous or clonic, or may pass from aclonic to a continuous condition, and may be associated with spasm of other ocular muscles. Among the examined 300 children in the age of 7-10 years a tendency of low myopia was observed (from - 0.5 to -3.0 SD) among 229 children. Typical accommodative spasm occurred among 10 children (to 8.0 SD). Although a refractive examination indicated accommodative spasm among the children, good visual acuity (1.0-0.9) remained. We were concerned with the question of what factors may predispose children to accommodative spasm among 7-10-year-olds, and if muscle balance of both eyes, especially during near vision work, can be involved in this. According to Schor et al., although phoria is determined by mechanical, neuronal and sensory factors, for most people when looking far, horizontal ortophoria or 
slight exophoria (up to 2.0 PD) predominates, which suggests the existence of mechanisms leading to ortophorization in the visual system [17].

The reference intervals for dissociated phoria were established by Meredith Morgan on the basis of the clinical trials she carried out. The results of her studies were published in 1944 [18]. The norm for dissociated horizontal phoria to far are values from o (ortophoria) to 2 PD BN (exophoria); for dissociated vertical phoria to far the norm ranges from 0 (ortophoria) to 0.5 PD vertical deviation in the upward or downward direction. Among children with a visual acuity of 1.0 (218 people) while looking far, an exophoria of up to 2.0 PD or a slight exophoria up to 1 PD was present. Among $80 \%$ of the examined subjects ( 158 children) with exophoria to near, a weakened or a lack of convergence was present. Based on our research we can assert that preventive screening of school children, which is often limited to only visual acuity and refractive error examinations, is insufficient in predicting the quality of vision in adulthood. Children 7-10 years and even older may not understand symptoms occurring in them (fatigue, periodic headaches, vision disturbances, difficulty reading, aversion to learning), and may not associate them with prolonged visual near work. In the examined group of 300 children, despite such a young age, we observed disturbing symptoms, which in the future may lead to vision problems during the education period, as well as in adulthood. We emphasize the value of phoria examination, especially in school children. Long-term observation of objects up close is associated with an enormous effort linked with directing both eyes at the viewed image and with appropriate accommodation tension, which allows the reception of a clear image. Weakened convergence additionally increases this effort. In the prevention of myopia, starting from the earliest age, attention should be paid to proper habits during visual work, taking breaks, and ensuring adequate oxygenation of the eyes by being outdoors or playing sports.

\section{CONCLUSIONS}

The carried out survey revealed that symptoms such as headaches and ocular pain are reported by individuals among whom horizontal dissociated phoria departs from accepted norms.
Difficulties with concentration while reading occur most often among people with impaired horizontal phoria to near.

Symptoms of an asthenopic character are mostly reported by individuals with abnormal values of dissociated phoria.

\section{REFERENCES}

1. Goldstein JH, Schneekloth BB. Spasm of the near reflex: a spectrum of anomalies. Surv Ophthalmol 1996;40(4):269-78.

2. Michaels DD. Accommodation: clinical aspects. In: Smirth RE, editor. Focal Points 1987: Clinical modules for ophthalmologists. San Francisco: American Academy of Ophthalmology; 1987.

3. Puchalska-Niedbał L, Baranowska-George T. Zaburzenie akomodacji jako przyczyna bólów głowy - doniesienie wstępne. Okulistyka 2005; 8:61-3.

4. Faucher C, Guise D. Spasm of the near reflex triggered by disruption of normal binocular vision. Optom Vis Sci 2004;81(3):178-81.

5. Rustein RP. Accommodative spasm in siblings: A unique finding. Indian J Ophthalm 2010;58(1):326-7. doi: 10.4103/0301-4738.64123.

6. Burian HM. Intermittent (facultative) divergent strabismus: its influence on visual acuity and the binocular visual act. Am J Ophthalmol 1945;28(1):525-7.

7. Seaber JH. Pseudomyopia in exodeviations. Am Orthopt J 1966;16(1): 67-72.

8. Rutstein RP, Daum KM, Amos JF. Accommodative spasm: a study of 17 cases. J Am Optom Assoc 1988;59(7):527-38.

9. Rutstein RP, Marsh-Tootle W. Acquired unilateral visual loss attributed to an accommodatie spasm. Optom Vis Sci 2001;78(7):492-5.

10. Shimojyo H, Kitaguchi Y, Asonuma S, Matsushita K, Fujikado T. Age-related changes of phoria myopia in patients with intermittent exotropia. Jpn J Ophthalmol 2009;53(1):12-7. doi: 10.1007/s10384-008-0602-2.

11. Benjamin W. Borish's clinical refraction. St. Louis: Butterworth Heinemann; 2008.

12. Richler A, Bear JC. Refraction, nearwork and education. A population study in Newfoundland. Acta Ophthalmol (Copenh) 1980;58(3):468-78.

13. Rosner M, Belkin M. Intelligence, education, and myopia in males. Arch Ophthal 1987;105(11):1508-11.

14. Teasdale TW, Goldschmidt E. Myopia and its relationship to education, intelligence and height. Preliminary results from an on going study of Danish draftees. Acta Ophthalmol Suppl 1988;185:41-3.

15. Saw SM, Wu HM, Seet B, Wong TY, Yap E, Chia KS, et al. Academic achievement, close up work parameters, and myopia in Singapore military conscripts. Br J Ophthalmol 2001;85:855-60.

16. Konstantopoulos A, Yadegarfar G, Elgohary M. Near work, education, family history, and myopia in Greek conscripts. Eye 2008;22(4):542-6. doi: $10.1038 /$ sj.eye.6702693.

17. Schor CM, Maxwell J, McCandless J, Graf E. Adaptive control of vergence in humans. Ann N Y Acad Sci. 2002;956:297-305.

18. Banks MS, Aslin RN, Letson RD. Sensitive period for the development of human binocular vision. Science 1975;190:675-7. 